\title{
PENGARUH JEJARING SOSIAL, LINGKUNGAN SEKOLAH DAN MOTIVASI BELAJAR TERHADAP PRESTASI BELAJAR EKONOMI PADA JURUSAN IPS SMA NEGERI DI KABUPATEN POLEWALI MANDAR
}

\author{
${ }^{1}$ Supiati \\ Program Pascasarjan Universitas Negeri makassar \\ supiati.kadir@gmail.com
}

\begin{abstract}
Abstrack
The study aims at examining (1) the direct influence of social network and school environment on learning motivation in IPS (Social Sciences) Department at public senior high schools in Polewali Mandar distric, (2) the direct influence of social network, schools environment, and learning motivation on learning achievement in Economy subject in IPS Department at public senior high schools in Polewali Mandar district, and (3) the indirect influence of social networl and schools environment on learning achievement in Economy. Subject through learning motivation in IPS Department at public senior high schools in Polewali Mandar district. The study was ex post facto research. Data were collected through questionnarire from respondents. Samples were selected by employing stratified random sampling technique and obtained 152 students. The measurement instrument used in this study was questionnaire and had been validated by the assessors consisted of content validation and empirical validation. Dta obtained were analyzed by employing path analysis. The results of the study reveal that (i) there is direct influence of social network and school environtment on learning motivation of grade XI in IPS Department at public senior high schools in Polewali Mandar, (ii) there is direct influence of social network, school environment, and learning motivation on learning achievement in economy subject in IPS Department at public senior high schools in Polewali Mandar, and (iii) there is indirect influence of social network and school environment on learning achievement in Economy subject through learning motivation in IPS Department at public senior high schools in Polewali Mandar district.
\end{abstract}

\section{Abstrak}

Adapun tujuan dalam penelitian ini yaitu untuk Mengetahui; (1) pengaruh langsung jejaring sosial dan lingkungan sekolah terhadap motivasi belajar pada Jurusan IPS SMA Negeri di Kabupaten Polewali Mandar, (2) pengaruh langsung jejaring sosial, lingkungan sekolah dan motivasi belajar terhadap prestasi belajar ekonomi pada Jurusan IPS SMA Negeri di Kabupaten Polewali Mandar, (3) pengaruh tidak langsung jejaring sosial dan lingkungan sekolah terhadap prestasi belajar ekonomi melalui motivasi belajar pada Jurusan IPS SMA Negeri di Kabupaten Polewali Mandar. Penelitian ini adalah penelitian ex post facto, jenis penelitian yang proses pengumpulan datanya dilakukan melalui angket dari sejumlah responden.. Teknik yang digunakan dalam pengambilan sampel ini adalah random sampling, sampel dalam penelitian ini terdiri dari 152 peserta didik. Instrumen pengukuran yang digunakan dalam penelitian ini adalah angket dan telah divalidasi oleh validitor ahli meliputi: Validasi Isi dan Validasi Empirik. Data yang diperoleh dianalisis dengan analisis jalur. Berdasarkan hasil penelitian menunjukkan; (i) Terdapat pengaruh langsung jejaring sosial dan lingkungan sekolah terhadap motivasi belajar kelas XI pada jurusan IPS SMA Negeri di kabupaten Polewali Mandar. (ii) Terdapat pengaruh langsung jejaring sosial, lingkungan sekolan dan motivasi belajar terhadap prestasi belajar ekonomi pada jurusan IPS SMA Negeri di kabupaten Polewali Mandar. (iii) Terdapat pengaruh tidak langsung jejaring sosial dan lingkungan sekolah terhadap prestasi belajar ekonomi melalui motivasi belajar pada jurusan IPS SMA Negeri di kabupaten Polewali Mandar.

Keywords: social network, school environtment, learning motivation, learning achievement. 


\section{Introduction}

Perkembangan zaman, ilmu pengetahuan dan teknologi telah berkembang semakin maju. Ilmu pengetahuan dan teknologi yang semakin maju tentunya mempengaruhi perkembangan informasi dan komunikasi. Kebutuhan masyarakat akan teknologi mendukung terciptanya alatalat komunikasi yang semakin lama semakin canggih Teknologi juga banyak menghasilkan mesin dan alat-alat lain yang dapat memudahkan manusia untuk berkomunikasi. Komunikasi yang dulunya memerlukan waktu yang lama dalam penyampaiannya kini dengan teknologi segalanya menjadi sangat dekat dan tanpa jarak. Internet menyediakan berbagai layanan yang dapat dimanfaatkan dengan mudah oleh penggunanya. Salah satu layanan internet ini adalah situs jejaring sosial. Jejaring Sosial yang dimaksud adalah sebuah situs web berbasis pelayanan dan dilakukan secara online yang memungkinkan penggunanya untuk membuat profil, melihat daftar pengguna yang tersedia serta mengundang atau menerima teman untuk bergabung dalam situs tersebut.

Jejaring sosial adalah sebuah media berbasis web untuk bersosialisasi satu sama lain dan dilakukan secara online baik melalui handphone maupun komputer. Contoh situs jejaring sosial adalah, You Tube, Facebook, Twitter, Instagram, Line, Whats App dan lain-lain. Keberadaan situs jejaring sosial memudahkan penggunanya untuk berinteraksi dengan orang-orang dari seluruh dunia dengan biaya yang lebih murah dibandingkan menggunakan telepon. Jejaring sosial saat ini telah menguasai kehidupan para pengguna internet. Layanan yang dihadirkan oleh masingmasing situs jejaring sosial berbeda-beda. Hal inilah yang merupakan ciri khas dan juga keunggulan masing-masing situs jejaring sosial. Pemanfaatan situs jejaring sosial atau social networking telah menjadi trend atau gaya hidup bagi sebagian masyarakat. Buktinya situs jejaring sosial Facebook berada pada peringkat pertama website yang paling banyak diakses di Indonesia. Sebagian besar pengguna berusia 15-39 tahun. Ini menunjukkan bahwa pengguna situs jejaring sosial adalah dari kalangan remaja usia sekolah.

Dengan peningkatan penggunaan internet dan situs jejaring sosial khususnya dikalangan usia sekolah diharapkan dapat meningkatkan prestasi belajar. Menurut Hamdani (2011: 138) mengemukakan bahwa "Prestasi belajar merupakan hasil pengukuran dari penilaian usaha belajar yang dinyatakan dalam bentuk simbol, huruf, maupun kalimat yang menceritakan hasil yang sudah dicapai oleh setiap anak pada periode tertentu".

Menurut Djamarah (2002: 204), "Sekolah adalah tempat pengabdian guru dan rumah rentabilitas anak didik". Kenyamanan dan ketenangan anak didik dalam belajar ditentukan oleh kondisi dan sistem sosial di sekolah dalam menyediakan lingkungan sekolah yang kondusif dan kreatif. Sarana dan prasarana yang ada di sekolah harus mampu dan memberikan layanan yang memuaskan bagi anak didik untuk berinteraksi dan hidup di dalamnya.

Berkaitan dengan prestasi belajar ekonomi, motivasi belajar sangatlah diperlukan. Menurut Dalyono (2009: 55), "Motivasi adalah daya penggerak/pendorong untuk melakukan sesuatu pekerjaan, yang berasal dari dalam diri dan juga dari luar". Menurut Sugihartono, dkk (2007: 78) motivasi belajar berperan penting untuk pencapaian prestasi belajar ekonomi, karena motivasi belajar yang tinggi akan terlihat dari ketekunan yang tidak mudah menyerah meskipun dihadapkan oleh beberapa kendala. Motivasi sangat berhubungan erat dengan perhatian dan sikap, guru berperan sangat penting untuk mendorong siswa agar dapat belajar dengan penuh perhatian. Sehingga penting bagi guru untuk memotivasi para siswa agar tetap belajar dengan giat dan keinginan dari dalam diri siswa supaya mampu memotivasi dirinya sendiri agar mampu menerima materi dengan baik.

Penelitian ini penting untuk dilakukan karena penggunaan situs jejaring sosial dikalangan peserta didik yang berlebihan, bisa memberikan dampak yang negatif seperti menurunya prestasi belajar siswa. Dalam hal ini kondisi lingkungan sekolah menjadi perhatian karena faktor ini sangat dekat dengan kehidupan sehari-hari siswa. Sekolah merupakan salah satu tempat belajar yang memberikan bermacam-macam pelajaran seperti mata pelajaran ekonomi yang harus 
ditempuh oleh para siswa IPS SMA Negeri di Kabupaten Polewali Mandar untuk mewujudkan suatu tujuan yang ingin dicapai. Lingkungan sekolah yang kondusif dapat memberikan motivasi belajar ekonomi yang tinggi yang diharapkan mampu memperbaiki prestasi belajar peserta didik dalam pelajaran ekonomi di SMA Negeri Kabupaten Polewali Mandar.

Peningkatan Penggunaan situs jejaring sosial di kalangan pelajar merupakan suatu fenomena yang perlu diteliti dengan mengacu pada berbagai indikasi yang menunjukkan bahwa mutu pembelajaran ekonomi di kelas XI IPS SMA Negeri di Kabupaten Polewali Mandar belum menunjukkan hasil secara signifikan, meskipun telah banyak upaya yang dilakukan oleh guru, namun dalam kenyataannya mutu pembelajaran masih tetap rendah. Rendahnya hasil pembelajaran ekonomi ini tercermin pada prestasi belajar peserta didik yang salah satu tolak ukurnya adalah nilai ujian akhir semester. Hal ini terjadi di SMA Negeri Kabupaten Polewali Mandar, bahwa prestasi belajar peserta didik pada mata pelajaran ekonomi masih rendah dibawah nilai KKM 7,5. Data yang diperoleh dari Kurikulum Dinas Pendidikan Kabupaten Polewali Mandar menunjukkan bahwa nilai rata-rata ujian akhir semester peserta didik SMA Negeri Kabupaten Polewali Mandar untuk mata pelajaran ekonomi relative rendah, dapat dilihat pada table berikut:

Tabel 1 Rata-rata Nilai Semester Akhir Mata Pelajaran Ekonomi Peserta Didik SMA Negeri di Kabupaten Polewali Mandar Tahun 2017.

\begin{tabular}{ll}
\hline \multicolumn{1}{c}{ Sekolah } & Rata-rata Nilai Akhir Semester \\
\hline 1. SMAN 1 Polewali & 5,71 \\
2. SMAN 2 Polewali & 5,76 \\
3. SMAN 3 Polewali & 5,97 \\
4. SMAN 1 Wonomulyo & 5,57 \\
5. SMAN 1 Campalagian & 5,43 \\
6. SMAN1 Tinambung & 5,73 \\
\hline
\end{tabular}

Sumber: Dinas Pendidikan Polewali Mandar, pada Tanggal 14 September 2017

Faktor rendahnya nilai peserta didik ini karena banyak peserta didik mengalami (1) peserta didik lebih banyak menghabiskan waktu membuka situs jejaring sosial dibandingkan membuka buku pelajaran ekonomi (2) tidak familiar dengan istilah ekonomi sehingga mengalami kesulitan dalam memahami materi; (3) keterbatasan guru dalam mendesain dan mengelolah serta menerapkan strategi pembelajaran dan tidak menerapkan multimedia pembelajaran sehingga membuat peserta didik kurang tertarik dalam mempelajari ekonomi (4) kurangnya minat, kreativitas dan motivasi, peserta didik untuk belajar ekonomi. (Sumber: Hasil wawancara guru ekonomi SMA Negeri 1 Polewali Tanggal 14 September 2017).

Menurut (Damsar, 2009: 160) situs jejaring sosial dapat memberikan informasi yang dibutuhkan dengan cepat, menambah wawasan dengan mencari tugas melalui aplikasi pendidikan yang ada, menambah teman, menyelesaikan tugas ekonomi dengan membuat grupgrup khusus untuk berdiskusi mata pelajaran ekonomi serta dapat mengundang teman lain untuk berdiskusi bersama. Dengan jejaring sosial siswa akan mampu belajar cara mengembangkan kemampuan teknis dan sosial yang dibutuhkan mereka dalam menghadapi era digital sekarang ini.

Namun pemakaian situs jejaring sosial yang berlebihan dapat menimbulkan banyak masalah di kehidupan nyata, terlebih dampak nyatanya pada dunia pendidikan. Motivasi siswa kini menurun, minat siswa untuk mengikuti pelajaran juga mulai mengalami penurunan dan prestasi belajarnyapun menurun. Kurangnya waktu belajar juga merupakan implikasi dampak negatif dari situs jejaring sosial. 
Menurut Sukmadinata (2009: 164), "lingkungan sekolah memegang perananan penting bagi perkembangan belajar para siswanya". Sedangkan menurut Sabdulloh (2010: 196) bahwa: Sekolah merupakan lingkungan pendidikan yang secara sengaja dirancang dan dilaksanakan dengan aturan-aturan yang ketat seperti harus berjenjang dan berkesinambungan, sehingga disebut pendidikan formal dan sekolah adalah lembaga khusus untuk menyelenggarakan pendidikan, yang di dalamnya terdapat suatu proses belajar mengajar untuk mencapai tujuan pendidikan tertentu.

Proses belajar mengajar itu memerlukan ruang dan lingkungan pendukung untuk dapat membantu siswa dan guru agar dapat berkonsentrasi dalam belajar karena konsentrasi yang baik dapat memotivasi siswa dalam menerima pelajaran dengan baik yang pada akhirnya dapat meningkatkan prestasi belajara dan mutu pendidikan. Unsur lingkungan sekolah yang memengaruhi prestasi belajar diantaranya metode mengajar, kurikulum, relasi guru dengan siswa, relasi siswa dengan siswa, disiplin sekolah dan fasilitas sekolah.

Motivasi belajar dapat timbul karena faktor intrinsik, berupa hasrat dan keinginan berhasil dan dorongan kebutuhan belajar, harapan akan cita-cita. Sedangkan faktor ekstrinsiknya adalah adanya penghargaan, lingkungan belajar yang kondusif, dan kegiatan belajar yang menarik. Tetapi harus diingat, kedua faktor tersebut disebabkan oleh rangsangan tertentu, sehingga seseorang berkeinginan untuk melakukan aktivitas belajar yang lebih giat dan semangat.

Motivasi belajar memiliki beberapa peran dalam proses belajar dan pembelajaran (Hamzah B. Uno, 2014: 27-28) sebagai berikut:

a. Peran dalam penguatan belajar. Motivasi dapat berperan dalam penguatan belajar apabila seorang anak yang belajar dihadapkan pada suatu masalah yang memerlukan pemecahan, yang dapat dipecahkan berkat bantuan yang pernah dilaluinya.

b. Peran dalam memperjelas tujuan belajar. Peran ini kaitannya dengan makna belajar, jika yang dipelajari itu sedikit sudah diketahui manfaatnya.

c. Peran dalam menentukan ketekunan belajar. Telah temotivasi untuk belajar sesuatu, akan berusaha mempelajarinya dengan baik dan tekun belajar, agar mendapatkan hasil yang baik. Motivasi bertujuan untuk mendorong.

Hamzah B. Uno dan Kuadrat (2009: 21-22) menyebutkan bahwa indikator motivasi belajar adalah sebagai berikut:

a. Tekun menghadapi tugas, siswa yang mempunyai motivasi belajar yang tinggi maka akan cenderung tekun dalam mengerjakan tugas yang diberikan oleh guru. Ketekunan dalam menghadapi tugas dapat dideskripsikan dapat menyelesaikan tugas tepat waktu dan tidak akan berhenti sebelum tugas terselesaikan.

b. Ulet menghadapi kesulitan, dalam menghadapi soal yang sulit, siswa pantang menyerah mendapatkan jawabannya. Dengan cara mencari diberbagai sumber belajar, misalnya internet.

c. Adanya dorongan dan keinginan, siswa mempunyai dorongan dan keinginan yang kuat untuk belajar, untuk mendapatkan prestasi belajar yang memuaskan.

d. Selalu berusaha berprestasi sebaik mungkin, siswa yang mempunyai motivasi belajar akan selalu berusaha untuk mendapatkan hasil belajar yang sebaik mungkin sehingga mendapatkan prestasi belajar yang maksimal juga.

e. Keberanian dalam mepertahankan pendapat, siswa mampu mempertahankan pendapat saat diskusi dan mempunyai keberanian untuk mengutarakan pendapat, merupakan ciri siswa yang mempunyai motivasi yang tinggi.

f. Kerajinan dan penuh semangat, siswa yang mempunyai motivasi belajar yang tinggi akan lebih rajin belajar dan penuh semangat dalam belajar. Siswa akan dengan senang hati belajar tanpa ada yang memaksa. 
g. Senang mencari dan memecahkan masalah, siswa aktif dalam mencari dan memecahkan soal untuk menambah wawasan, hal itu menandakan sisiwa mempunyai motivasi yang tinggi.

Menurut Tohirin (2008: 151) "Prestasi belajar diperoleh dari apa yang telah dicapai oleh siswa setelah siswa melakukan kegiatan belajar". Prestasi belajar berkaitan dengan nilai yang diberikan guru untuk mengetahui hasil akhir dalam waktu tertentu. Prestasi Belajar juga merupakan pengukuran kemampuan siswa dalam mata pelajaran tertentu yang biasanya ditunjukkan dalam bentuk nilai atau huruf oleh guru yang bersangkutan.

Faktor-faktor yang mempengaruhi prestasi belajar, baik yang berasal dari dirinya intern maupun dari luar dirinya ekstern. Prestasi belajar ekonomi yang dicapai siswa pada hakikatnya merupakan hasil interaksi antara berbagai faktor. Oleh karena itu, pengenalan guru terhadap faktor-faktor yang dapat mempengaruhi prestasi belajar ekonomi penting dalam rangka membantu siswa mencapai prestasi belajar ekonomi seoptimal mungkin dengan kemampuan masing-masing.

Menurut Ngalim Purwanto (2007: 102), faktor-faktor yang memengaruhi belajar dibedakan menjadi dua golongan yaitu:

a. Faktor yang ada pada diri organisme itu sendiri yang kita sebut faktor individual, dan

b. Faktor yang ada diluar individu yang kita sebut faktor sosial. Yang termasuk kedalam faktor individual antara lain: faktor kematangan/pertumbuhan, kecerdasan, latihan, motivasi, dan faktor pribadi.

c. Faktor sosial yang termasuk faktor sosial antara lain: faktor keluarga/keadaan rumah tangga, guru dan cara mengajarnya, alat-alat yang digunakan dalam belajar mengajar, lingkungan dan kesempatan yang tersedia serta motivasi sosial.

Ketiga ranah diatas dapat digunakan untuk mengukur prestasi belajar ekonomi siswa. Faktor-faktor di atas dapat menimbulkan siswa berprestasi tinggi dan siswa yang berprestasi rendah atau gagal sama sekali. Oleh karena itu, baik dalam lingkungan belajar guru mampu mengantisipasi munculnya siswa yang menunjukkan gejala kegagalan dengan berusaha mengatasi faktor yang menghambat proses belajar siswa tersebut.

Adapun tujuan yang hendak dicapai dalam penelitian ini yaitu; ; (1) untuk mengetahui pengaruh langsung jejaring sosial dan lingkungan sekolah terhadap motivasi belajar pada Jurusan IPS SMA Negeri di Kabupaten Polewali Mandar, (2) untuk mengetahui pengaruh langsung jejaring sosial, lingkungan sekolah dan motivasi belajar terhadap prestasi belajar ekonomi pada Jurusan IPS SMA Negeri di Kabupaten Polewali Mandar, (3) untuk mengetahui pengaruh tidak langsung jejaring sosial dan lingkungan sekolah terhadap prestasi belajar ekonomi melalui motivasi belajar pada Jurusan IPS SMA Negeri di Kabupaten Polewali Mandar.

\section{Method}

\section{JENIS PENELITIAN}

Jenis Jenis penelitian ini merupakan penelitian ex post facto yang bersifat pengaruh dan bertujuan melihat pengaruh jejaring sosial, lingkungan sekolah dan motivasi belajar terhadap prestasi belajar ekonomi tanpa adanya suatu perlakuan yang diterapkan.

\section{TEKNIK PENGUMPULAN DATA}

Teknik pengumpulan data dalam penelitian ini dikumpulkan melalui teknik kuisioner. Teknik kuisioner merupakan alat yang digunakan dalam mengumpulkan informasi yang berkaitan dengan jejaring sosial, lingkungan keluarga, motivasi belajar dan prestasi belajar ekonomi siswa kelas X1 IPS SMA Negeri di Kabupaten Polewali Mandar. Teknik kuisioner 
merupakan pengumpulan data melalui pemberian daftar pertanyaan atau pernyataan kepada responden sesuai dengan variabel yang menjadi fokus penelitian.

TEKNIK ANALISIS DATA

Analisis deskriptif dilakukan dengan mencari nilai rata-rata dari data jejaring sosial, lingkungan sekolah dan motivasi belajar. Mencari rata-rata menggunakan rumus:

$$
\text { rata }- \text { rata }=\frac{\text { skorperolehan }}{\text { skortotal }} \times 100
$$

\section{UJI PRASYARAT ANALISIS}

Sebelum dilakukan analisis dengan teknik path analisis data-data tersebut harus diuji dahulu apakah data tersebut linier, normal atau tidak. Maka dalam penelitian ini dilakukan uji prasyarat uji normalitas data dan uji linearitas.

\section{Analisis Jalur (Path Analysis)}

Untuk melihat pengaruh antar variabel baik langsung maupun pengaruh tidak langsung, dilakukan dengan metode analisis jalur (path analysis). Sebelum data dianalisis dengan path analysis tersebut maka peneliti terlebih dahulu merumuskan model konseptual dan kerangka pikir sekaligus menjadi hipotesis penelitian. Model konseptual tersebut dibuat berdasarkan kajian pustaka yang dilanjutkan dengan pengspesifikasian model dengan simbol-simbol statistik tertentu. Analisis jalur dapat dilihat pada gambar berikut:

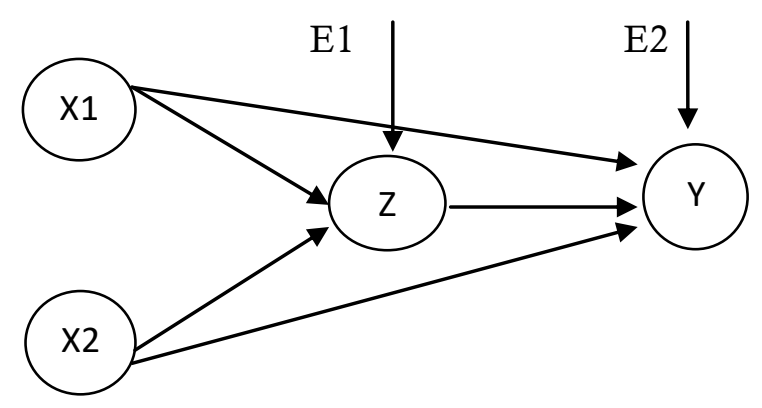

Gambar 1 Diagram model path analisis penelitian

Keterangan:

$$
\begin{array}{ll}
\mathrm{X} 1, \mathrm{X} 2, \mathrm{Z} \text {, dan } \mathrm{Y} & : \text { variabel penelitian } \\
\mathrm{E} 1, \mathrm{E} 2 & : \text { faktor residual }
\end{array}
$$

Melalui model atau diagram analisis jalur ini, variabel X1 dan X2 disebut variabel eksogen, sedangkan variabel $\mathrm{Z}$ dan $\mathrm{Y}$ di sebut variabel endogen.

\section{Results and Discussions}

Analisis Jejaring Sosial

Tabel 2 Data persepsi peserta didik tentang jejaring sosial pada jurusan IPS SMA Negeri di Kabupaten Polewali Mandar

\begin{tabular}{ccccc}
\hline No & Interval & Frekuensi & Persentase & Kategori \\
\hline 1. & $78-89$ & 36 & $23,7 \%$ & Baik Sekali \\
2. & $66-76$ & 81 & $53,3 \%$ & Baik \\
3. & $55-65$ & 28 & $18,4 \%$ & Sedang \\
4. & $44-54$ & 5 & $3,3 \%$ & Kurang \\
5. & $33-43$ & 2 & $1,3 \%$ & Kurang Sekali \\
\hline & Jumlah & 152 & $100 \%$ & \\
\hline
\end{tabular}


Berdasarkan data pada tabel 2 dapat dikemukakan bahwa pada persepsi peserta didik tentang jejaring sosial berada pada kategori baik. Dari hasil tersebut diketahui bahwa instrmen yang digunakan untuk mengukur jejaring sosial ada pada kategori baik dengan frekuensi 81 sehingga dapat dikemukakan bahwa peserta didik sering mengakses situs jejaring sosial untuk mencari informasi dan berdiskusi melalui grup media sosial terkait pelajaran. Peserta didik membuka situs jejaring sosial setiap hari untuk mendapatkan informasi terkait pelajaran dan untuk menyelesaikan tugas yang diberikan. Peserta didik memiliki akun media sosial seperti Facebook, Instagram dan WhatsApp. Peseta didik membuka situs jejaring sosial melalui handphone dan melalui warnet.

Berdasarkan penjelasan dari tabel dan hasil perhitungan Pengguna jejajring sosial pada jurusan IPS SMA Negeri di Kabupaten Polewali Mandar berada pada kategori baik terhadap prestasi belajar ekonomi.

\section{Analisis Lingkungan Sekolah}

Tabel 3 Data Lingkungan Sekolah pada jurusan IPS SMA Negeri di Kabupaten Polewali Mandar

\begin{tabular}{ccccc}
\hline No & Interval & Frekuensi & Persentase & Kategori \\
\hline 1. & $114-126$ & 13 & $8,7 \%$ & Baik Sekali \\
2. & $101-113$ & 50 & $32,8 \%$ & Baik \\
3. & $89-100$ & 59 & $38,7 \%$ & Sedang \\
4. & $77-88$ & 23 & 15,2 & Kurang \\
5. & $65-76$ & 7 & 4,6 & Kurang Sekali \\
\hline & Jumlah & 152 & $100 \%$ & \\
\hline
\end{tabular}

Berdasarkan data pada tabel 3 dapat dikemukakan bahwa pada persepsi peserta didik tentang lingkungan sekolah berada pada kategori sedang. Dari hasil tersebut diketahui bahwa instrmen yang digunakan untuk mengukur lingkungan sekolah ada pada kategori sedang dengan frekuensi 59. Dapat dikemukakan bahwa peserta didik lebih menyukai metode pembelajaran menggunakan internet sehingga guru perlu mengembangan metode mengajar yang bersumber dari internet dan membuat grup belajar melalui media sosial agar lebih dekat dengan peserta didik. Sekolah masih perlu melengkapi fasilitas seperti laboratorium komputer dan jaringan WIFI untuk memudahkan peserta didik mengakses informasi terkait pembelajaran.

\section{Analisis Motivasi Belajar}

Tabel 4 Data Motivasi Belajar pada jurusan IPS SMA Negeri di Kabupaten Polewali Mandar

\begin{tabular}{ccccc}
\hline No & Interval & Frekuensi & Persentase & Kategori \\
\hline 1. & $119-130$ & 9 & $6 \%$ & Baik Sekali \\
2. & $106-118$ & 55 & $36 \%$ & Baik \\
3. & $93-105$ & 58 & $38,1 \%$ & Sedang \\
4. & $80-92$ & 27 & $17,9 \%$ & Kurang \\
5. & $66-79$ & 3 & $2 \%$ & Kurang Sekali \\
\hline & Jumlah & 152 & $100 \%$ & \\
\hline
\end{tabular}

Berdasarkan data pada tabel 4 dapat dikemukakan bahwa pada persepsi peserta didik tentang motivasi belajar berada pada kategori sedang. Dari hasil tersebut diketahui bahwa indikator yang digunakan untuk mengukur motivasi belajar yakni: tekun dalam menyelesaikan tugas, ulet 
menghadapi kesulitan adanya dorongan dan upaya untuk berprestasi, kerajinan dan senang memecahkan masalah-masalah belajar berada pada kategori sedang dengan frekuensi 58 .

Berdasarkan penjelasan dari tabel dan hasil perhitungan motivasi belajar pada jurusan IPS SMA Negeri di Kabupaten Polewali Mandar berada pada kategori sedang terhadap prestasi belajar ekonomi.

\section{Analisis Prestasi Belajar}

Berdasarkan data diatas menunjukkan prestasi belajar ekonomi peserta didik pada jurusan IPS SMA Negeri di Kabupaten Polewali Mandar dengan nilai rata-rata 81,28. Nilai terendah yaitu 58 dan nilai tertinggi 92 dengan standar deviasi 6,30 ini lebih rendah penyimpangan data dari rata-rata hitungnya artinya penyebaran data lebih homogen.

Tabel 5 Data Pestasi Belajar Ekonomi Peserta Didik Pada Jurusan IPS SMA Negeri di Kabupaten Polewali Mandar

\begin{tabular}{ccccc}
\hline No & Interval & Frekuensi & Persentase & Kategori \\
\hline 1. & $86-92$ & 35 & $23, \%$ & Baik Sekali \\
2. & $79-85$ & 73 & $48,1 \%$ & Baik \\
3. & $72-78$ & 33 & $21,7 \%$ & Sedang \\
4. & $65-71$ & 7 & $4,6 \%$ & Kurang \\
5. & $58-64$ & 4 & $2,6 \%$ & Kurang Sekali \\
\hline & Jumlah & 152 & $100 \%$ & \\
\hline
\end{tabular}

Berdasarkan data pada tabel 5 dapat dikemukakan bahwa prestasi belajar ekonomi peserta didik berada pada kategori baik, dengan frekuensi 73 sehingga dapat dikemukakan bahwa kemampuan peserta didik pada pelajaran ekonomi jurusan IPS SMA Negeri di Kabupaten Polewali Mandar berada pada kategori baik terhadap prestasi belajar.

\section{PATH ANALYSIS}

Langkah-langkah untuk analisis jalur pada penelitian ini adalah sebagai berikut:

1. Membuat model paradigm penelitian diagram jalur berdasarkan teori dan penelitian terdahulu. Analisis jalur dapat dilihat pada gambar berikut:

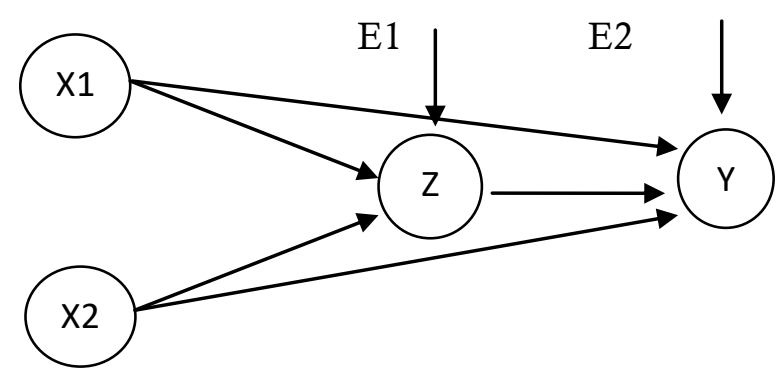

Gambar 2 Diagram model path analisis penelitian

2. Membuat diagram jalur, hipotesis dan persamaan strukturnya itu menyusun spesifikasi model analisis dengan cara mentransformasi model teoritik menjadi model analisis masingmasing sub struktur serta membuat struktur persamaan masing-masing sub struktur. Hubungan kausal dipaparkan pada uraian berikut: 


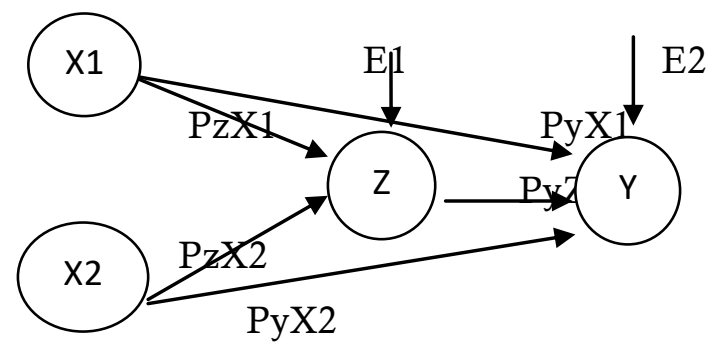

Gambar 3 Diagram jalur

\section{Keteragan:}

X1 : Jejaring Sosial

X2 : Lingkungan Sekolah

Z : Motivasi Belajar

Y : Prestasi Belajar

$\mathrm{P} \quad$ : Koefisien jalur

E1, E2 : variabel/faktor residual

Berdasarkan model hipotesis yang diajukan, maka dibuatlah sub struktur yang bertujuan untuk menjelaskan dan mempermudah perhitungan sebagai berikut:

(a). Sub struktur 1. Hubungan kausal langsung Jejaring sosial (X1), dan Lingkungan sekolah (X2) terhadap motivasi belajar (Z) dengan hipotesis operasional ada pengaruh langsung jejaring sosial dan lingkungan sekolah terhadap motivasi belajar. Gambar model hubungan kausal tampak sebagai berikut:

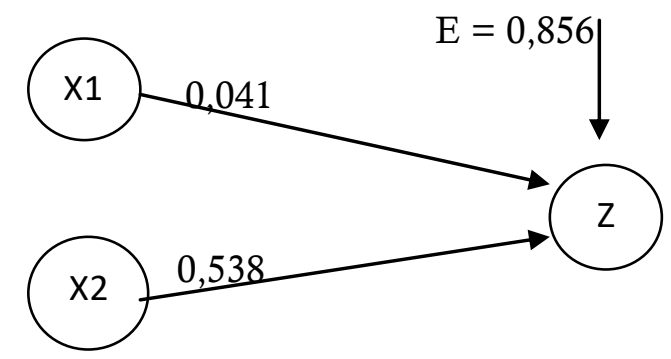

Gambar 4 Model hubungan langsung X1 dan X2 terhadap Z

Berdasarkan gambar diatas diperoleh nilai langsung X1 terhadap Z sebesar 0,041 dan nilai langsung X2 terhadap Z sebesar 0,538, sehingga dapat disimpulkan bahwa secara langsung terdapat pengaruh $\mathrm{X} 1$ dan $\mathrm{X} 2$ terhadap $\mathrm{Z}$

(b) Sub struktur 2. Hubungan kausal langsung jejaring sosial (X1), lingkungan sekolah (X2), dan motivasi belajar $(\mathrm{Z})$ terhadap prestasi belajar $(\mathrm{Y})$ dengan hipotesis ada pengaruh langsung jejaring sosial, lingkungan sekolah dan motivasi belajar terhadap prestasi belajar. Gambar model hubungan kausal sebagai berikut: 


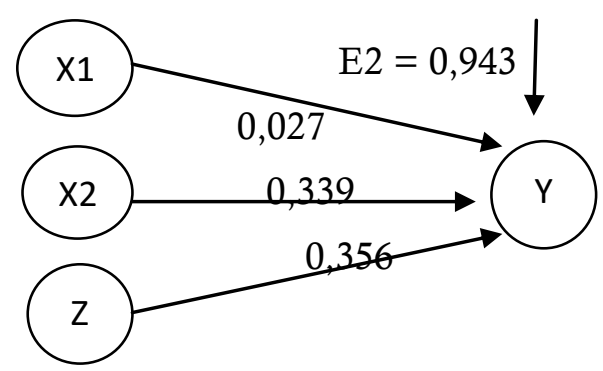

Gambar 5 Model hubungan langsung X1.X2 dan Z terhadap Y

Berdasarkan gambar diatas diperoleh nilai langsung X1 terhadap $Y$ sebesar 0,027, nilai langsung X2 terhadap $\mathrm{Y}$ sebesar 0,339 dan nilai langsung $\mathrm{Z}$ terhadap $\mathrm{Y}$ sebesar 0,356 sehingga dapat disimpulkan bahwa secara langsung terdapat pengaruh $\mathrm{X} 1, \mathrm{X} 2$ dan $\mathrm{Z}$ terhadap Y.

(c). Sub struktur 3. Hubungan tidak langsung antara variabel jejaring sosial (X1) dan lingkungan sekolah (X2), terhadap prestasi belajar (Y) melalui variabel motivasi belajar (Z) dengan hipotesis ada pengaruh tidak langsung jejaring sosial dan lingkungan sekolah terhadap prestasi belajar melalui motivasi belajar. Gambar model hubungan kausal tampak sebagai berikut:

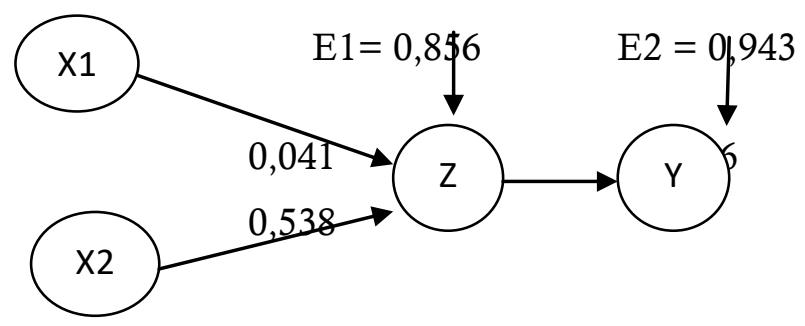

Gambar 6 Model hubungan tidak langsung $\mathrm{X} 1, \mathrm{X} 2$ dan $\mathrm{Z}$ terhadap $\mathrm{Y}$

Berdasarkan gambar diatas diketahui pengaruh tidak langsung $\mathrm{X} 1$ melalui $\mathrm{Z}$ terhadap $\mathrm{Y}$ yaitu: $0,041 \times 0,356=0.015$ dan pengaruh tidak langsung $X 2$ melalui $Z$ terhadap $Y$ yaitu $=$ $0,538 \times 0,356=0,192$. Sehingga dapat disimpulkan bahwa terdapat pengaruh tidak langsusng $\mathrm{X} 1$ dan $\mathrm{X} 2$ terhadap Y melalui $\mathrm{Z}$.

\section{PEMBAHASAN}

\section{Besarnya Pengaruh Jejaring Sosial terhadap Prestasi Belajar melalui Motivasi Belajar.}

Jejaring sosial berpengaruh secara langsung terhadap prestasi belajar, nilai pengaruh langsung jejaring sosial terhadap presasi belajar sebesar 0,027. Sedangkan pengaruh tidak langsung jejaring sosial terhadap prestasi belajar adalah sebesar 0,015 yang berarti nilai pengaruh langsung lebih besar dibandingkan pengaruh tidak langsung. Pengaruh langsung jejaring sosial terhadap prestasi belajar lebih besar karena siswa lebih senang mencari dan menyelesaikan tugas yang diberikan oleh guru melalui internet dan media sosial. Melalui media sosial siswa dapat berkomunikasi dengan teman dan guru untuk membahas materi pelajaran terkait. Hal ini sesuai dengan pendapat Damsar, 2009 yang menyatakan bahwa: situs jejaring sosial dapat memberikan informasi yang dibutuhkan dengan cepat, menambah wawasan dengan mencari tugas melalui aplikasi pendidikan yang ada, menambah teman, menyelesaikan tugas ekonomi dengan 
membuat grup-grup khusus untuk berdiskusi mata pelajaran ekonomi serta dapat mengundang teman lain untuk berdiskusi bersama.

Jejaring sosial juga memiliki pengaruh langsung terhadap motivasi belajar, dengan terbentuknya komunitas pertemanan yang luas, ini akan mampu memotivasi para siswa dalam mengembangkan diri dari materi atau masukan teman-teman baru mereka yang terhubung secara online. Meningkatnya motivasi belajar siswa dapat meningkatkan prestasi belajar mereka.

\section{Besarnya Pengaruh Lingkungan Sekolah terhadap Prestasi Belajar melalui Motivasi Belajar.}

Lingkungan sekolah berpengaruh secara langsung terhadap prestasi belajar, nilai pengaruh lingkungan sekolah terhadap presasi belajar sebesar 0,334. Sedangkan pengaruh tidak langsung lingkungan sekolah terhadap prestasi belajar adalah sebesar 0,191 yang berarti nilai pengaruh langsung lebih besar dibandingkan pengaruh tidak langsung. Lingkungan sekolah juga berpengaruh secara langsung terhadap motivasi belajar siswa sebagimana pendapat Sukmadinata (2009: 164), "lingkungan sekolah memegang perananan penting bagi perkembangan belajar para siswanya". Proses belajar mengajar itu memerlukan ruang dan lingkungan pendukung untuk dapat membantu siswa dan guru agar dapat berkonsentrasi dalam belajar karena konsentrasi yang baik dapat memotivasi siswa dalam menerima pelajaran dengan baik yang pada akhirnya dapat meningkatkan prestasi belajara dan mutu pendidikan.

Unsur lingkungan sekolah yang memengaruhi prestasi belajar diantaranya metode mengajar guru, kurikulum, relasi guru dengan siswa, relasi siswa dengan siswa, disiplin sekolah dan fasilitas sekolah. Lingkungan sekolah yang baik dapat meningkatkan motivasi belajar siswa dan motivasi belajar siswa yang baik dapat meningkatkan prestasi belajar.

\section{Besarnya Pengaruh Motivasi Belajar terhadap Prestasi Belajar}

Motivasi belajar berpengaruh secara langsung terhadap prestasi belajar, nilai pengaruh motivasi belajar terhadap presasi belajar sebesar 0,334. Pengaruh motivasi dalam kegiatan belajar yaitu bagaimana menciptakan kondisi yang mendorong siswa melakukan aktivitas belajar optimal. Motivasi yang tinggi dapat menggiatkan aktifitas belajar siswa. Siswa yang telah memiliki Motivasi Belajar yang tinggi akan memiliki keinginan dan harapan untuk berhasil dan bila mengalami kegagalan akan berusaha keras untuk mencapai keberhasilan yang ditunjukkan dengan Prestasi Belajar Ekonomi.

\section{Conclusions}

1. Jejaring sosial memiliki pengaruh langsung terhadap motivasi belajar dan jejaring sosial juga memiliki pengaruh tidak langsung terhadap prestasi belajar melalui motivasi belajar. Berdasarkan hasil perhitungan pengaruh langsung jejaring sosial terhadap prestasi belajar lebih besar daripada pengaruh tidak langsung sehingga terdapat pengaruh langsung maupun tidak langsung antara jejaring sosial dengan prestasi belajar ekonomi melalui motivasi belajar peserta didik pada jurusan IPS SMA Negeri di Kabupaten Polewali Mandar.

2. Lingkungan sekolah yang baik akan terdapat hubungan prestasi belajar yang lebih baik, hal ini sesuai dengan hasil perhitungan analisis jalur memperoleh nilai pengaruh langsung lingkungan sekolah lebih besar daripada pengaruh tidak langsung lingkungan sekolah terhadap prestasi belajar melalui motivasi belajar sehingga terdapat pengaruh antara lingkungan sekolah terhadap prestasi belajar ekonomi pada jurusan IPS SMA Negeri di Kabupaten Polewali Mandar.

3. Terdapat pengaruh langsung maupun pengaruh tidak langsung jejaring sosial, lingkungan sekolah dan motivasi belajar terhadap prestasi belajar, hal ini sesuai dengan hasil perhitungan analisis jalur sehingga terdapat pengaruh antara penggunaan jejaring sosial, lingkungan sekolah dan motivasi belajar terhadap prestasi belajar ekonomi pada jurusan IPS SMA Negeri di Kabupaten Polewali Mandar. 


\section{References}

Dalyono. 2009. Psikologi Pendidikan. Jakarta: Rineka Cipta.

Djamarah, Syaiful Bahri. 2002. Psikologi Belajar. PT. Rineka Cipta: Jakarta. 2005. Guru dan Anak Didik Dalam Interaksi Edukatif Suatu Pendekatan Teoretis Psikologis. Rineka Cipta: Jakarta.

Hamdani. 2011. Strategi Belajar Mengajar. Bandung : Pustaka Setia.

Hamzah B. Uno.2008. Orientasi Baru dalam Psikologi Pembelajaran. Jakarta: Bumi Aksara.

Nana Syaodih Sukmadinata. 2009. Metode Penelitian Pendidikan. Bandung: Rosdakarya.

Ngalim Purwanto. 2007. Psikologi Pendidikan. Bandung: PT Remaja Rosdakarya.

Sugihartono, dkk. 2007. Psikologi Pendidikan. Yogyakarta: UNY Press.

Tohirin. 2008. Bimbingan dan Konseling di Sekolah dan Madrasah (berbasis integrasi). Jakarta: Raja Grafindo Persada 